\title{
Leit að sökudólgum skaðar öryggi sjúklinga
}

\section{Birgir Jakobsson}

barnalæknir, sjúkrahússtjóri Karolinska Universitetssjukhuset

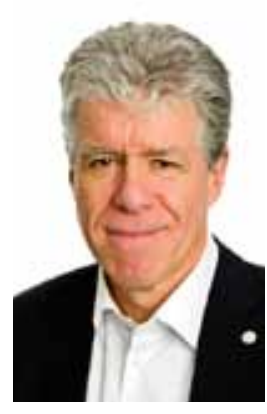

Birgir.jakobsson@karolinska.se

Gífurlega mikil próun hefur átt sér stað síðustu áratugi innan heilbrigðispjónustunnar. Sérstaklega á petta við um próun á sviði tækni og lyfja. Starfsfólk á sjúkrahúsum parf nú að hafa með höndum flókin tæki og öflug lyf og séu pau notuð á rangan hátt geta pau haft alvarlegar afleiðingar fyrir sjúklingana. Menntun heilbrigðisstétta og próun vinnubragða á spítölum hefur ekki haldið í við pessa próun. Í Svípjóð er talið að á hverju ári hljóti um 100.000 sjúklingar varanlegt mein af völdum óhappa í heilbrigðispjónustunni og að um 3000 sjúklingar bíði bana árlega af sömu ástæðu. Síðastliðinn áratug hefur skilningur á gildi svokallaðrar öryggismenningar farið vaxandi innan heilbrigðisgeirans. Heilbrigðisgeirinn lítur nú í auknum mæli til annarra starfsgreina sem hafa komist lengst á sviði öryggis, svo sem fluggeirans. Par ríkir skilningur á pví að öryggi farpega og starfsfólks er háo samspili á milli hins mannlega páttar við tækni og skipulag á vinnustað. Allir pessir pættir geta brugðist, hver fyrir sig, en sjaldan allir í einu. Í starfsemi sem einkennist af öryggishugarfari og öryggismenningu sér maður til pess að allir pættirnir prír vinni saman, pannig að ef einn peirra bregst grípur annar inn í. Stórslys gerast pegar tveir eða fleiri pættir bregðast samtímis.
Hingað til hafa óhöpp innan heilbrigðisstofnana verið rannsökuð eingöngu innan heilbrigðiskerfisins og af eftirlitsstofnunum pess, og par hefur próun síðustu ára verið sú að í auknum mæli er forðast að leita að sökudólgum og fremur leitað pess sem úrskeiðis fór og af hverju. Nú sýna aðrir geirar pjóðfélagsins aukinn áhuga á að fá innsýn í pessi mál. Fyrir skömmu var barnalæknir á Karolinska sjúkrahúsinu settur í gæsluvarðhald og ákærður fyrir að hafa bundið enda á líf dauðvona fyrirbura sem viðkomandi læknir meðhöndlaði í lok lífsins. Tveimur árum og einni eyðilagðri starfsævi síðar lauk málinu með pví að læknirinn var sýknaður. Рað er ólöglegt að flýta fyrir dauða sjúklings sem liggur á dánarbeði en pað er skylda hjúkrunarfólks að lina pjáningar í lok lífsins. Munurinn á pessu tvennu kann að virðast óljós fyrir pá sem ekki eru læknar eða hjúkrunarfólk en er augljós öllum sem hafa til pess menntun. Öll pessi atburðarás olli mikilli óvissu og ótta meðal starfsfólks á sjúkrahúsinu og stjórn sjúkrahússins neyddist til að verja miklum kröftum í að styðja barnalækninn og nánustu samstarfsmenn, ekki síst til að tryggja að meðferð dauðvona sjúklinga færi ekki úrskeiðis.

Í Svípjóð rannsakar svokölluð "stórslysanefnd" (Statens haverikommission) slys og alvarleg óhöpp sem gerast af völdum almenningssamgöngutækja eða í kjarnorkuverum. Fyrir nokkru barði pessi stofnun að dyrum Karolinska sjúkrahússins og vildi rannsaka óhapp sem hafði kostað sjúkling lífið. Óhappið var pegar í rannsókn samkvæmt hefðbundnum leiðum innan heilbrigðisgeirans. Niðurstaðan af pessum tveimur rannsóknum var að mestu samhljóða og án pess að bent væri á nokkurn sökudólg. Skýrsla „stórslysnefndar" var hins vegar mjög ýtarleg og lærdómsrík fyrir pað umbótarstarf sem hefur átt sér stað um árabil á Karolinska.

Hér eru tekin tvö dæmi, annars vegar par sem dómsvaldið grípur inn í gang mála til að finna hver sé ábyrgur og dæma viðkomandi til refsingar, og hins vegar "stórslysanefnd" sem hefur langa reynslu af pví að byggja upp öryggismenningu og skilur mikilvægi pess að rannsóknin beinist að pví að komast að „hvað“ gerðist og ekki „hver“ gerði pað. Hið síðarnefnda leiðir óhjákvæmilega til óvissu og hræðslu á vinnustað sem skapar hættu í sjálfu sér en einnig til pess að starfsfólk lætur vera að skýra frá frávikum og óhöppum sem annars gætu leitt til umbóta og aukins öryggis sjúklinga. Hin margpætta atburðarás sem oftast er undanfari alvarlegs óhapps gerir pað аð verkum að erfitt er að benda á nokkurn einstakan sem er ábyrgur. Fyrr eða síðar verður öllum á að gera mistök og pá ríður á að gera vinnustaðinn pannig úr garði að tæki og vinnuaðferðir minnki hættuna á alvarlegum afleiðingum pessara mistaka. Vinnuveitandinn ber ábyrgð á pví að pessu sé framfylgt á vinnustöðum par sem líf og heilsa fólks er í húfi.

Hlutverk dómsvaldsins er að túlka lögin og dæma til refsingar séu pau brotin. Að sjálfsögðu eiga landslög að ná jafnt til allra, einnig starfsfólks sjúkrahúsa. Löggjafarvaldinu ber hins vegar að sjá til pess að lögin taki fullt tillit til pess hvernig flókin hátæknistarfsemi, eins og heilbrigðisgeirinn er orðinn, byggir upp öryggismenningu.

"Shame and blame" threatens patient safety

Birgir Jakobsson MD, CEO of Karolinska University Hospital, Stockholm 